\title{
Sărbătoarea Schimbării la Faţă: de la imaginile biblice la istoria sărbătorii şi teologia ei imnografică
}

\author{
Gheorghe MIHALACHE *
}

\begin{abstract}
The Feast of the Transfiguration: From Biblical Images to the History of the Feast and Its Hymnographical Theology. The Transfiguration of the Lord is at the heart of Orthodox theology, because it represents the confirmation of man's possibility of knowing God. Thus, during the feast of the Transfiguration of the Lord, the believer makes a spiritual exercise to be included in the state of contemplation, a state characteristic of the Orthodox cult. The present study focuses concretely on certain particularities: it starts from the New Testament cupid of the soteriological event of the Transfiguration (emphasizing here, of course, the philological issues related to this event) and focuses on the history of the holiday and Byzantine implications in the introduction of this eulogy throughout the Christian space, doubled by theological hymnography (especially of Syrian origin, but rendered in the Byzantine Greek language).
\end{abstract}

Keywords: The Feast of the Transfiguration, biblical images, history, hymnography, theology

Pentru Biserica Ortodoxă, acţiunea soteriologică a lui Hristos nu aparţine numai trecutului. El nu priveşte acum numai din cer cum cei ce cred în eficienţa operei Lui mântuitoare din cursul vieţii pământeşti îşi însuşesc rezultatul jertfei Lui de pe Cruce, ajutaţi sau nu de o comunitate eclesială. După învăţătura Bisericii Ortodoxe, păstrătoare a învăţăturii creştine originare, relaţia credincioşilor cu

Asistent universitar asociat la Facultatea de Teologie Ortodoxă „Dumitru Stăniloae”, Universitatea „Alexandru Ioan Cuza” din Iaşi, România. 
Hristos nu este numai una prin amintirea recunoscătoare şi emoţionantă, adică numai una de ordin psihologic, ci şi o relaţie reală, întrucât ea este susţinută nu numai de noi, ci şi de Hristos Însuşi. Această relaţie reală este trăită în toate sărbătorile Bisericii, în toate Tainele şi în tot cultul Bisericii Ortodoxe ${ }^{1}$.

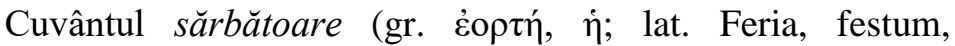
festivitas, solemnitas; slv. Prazdnic) este de origine latină (servatoria, de la servo-are, care înseamnă a păstra, a respecta, a conserva $)^{2}$. Prin urmare, a fi în stare de solemnitate înseamnă a intra în logica Tradiției, păstrând și transmiţând generațiilor următoare adevărul care izvorăște din viața lui Hristos. A fi parte a unei sărbători, îl pune pe credincios la aceeași masă cu Stăpânul și îi confirmă demnitatea de fiu al lui Dumnezeu. Schimbarea la Faţă a Domnului se află în centrul teologiei ortodoxe, pentru că reprezintă confirmarea posibilităţii omului de a-L cunoaşte pe Dumnezeu. Astfel, în cadrul sărbătorii Transfigurării Domnului, credinciosul face un exerciţiu duhovnicesc pentru a fi cuprins de starea de contemplare, stare caracteristică cultului ortodox.

Studiul de faţă se axează în mod concret pe anumite particularităţi: porneşte de la cupinsul neo-testamentar al evenimentului soteriologic al Schimbării la faţă (accentuând aici, desigur, şi problematicile filologice legate de acest eveniment) şi se centralizează pe istoricul sărbătorii şi implicaţiile bizantine în introducerea acestui panegiric în tot spaţiul creştin, dublat şi de imnografia teologică (de sorgine siriană în mod special, dar redată în limba greacă bizantină).

\section{Particularităţi ale textelor biblice care fac referire la evenimentul Schimbării la Față a Domnului}

Evanghelistul Ioan nu menţionează Schimbarea la Faţă, însă în capitolul al 12-lea, la sfârşitul vestirii pe care Iisus o face

${ }^{1}$ Dumitru StĂniloAe, „Drumul cu Hristos Mîntuitorul prin Tainele şi sărbătorile Bisericii Ortodoxe", în Ortodoxia 2 (1976), p. 402.

${ }^{2}$ Ene BranişTe, Ecaterina BranişTe, Dicţionar de cunoştinţe religioase, Sibiu, Edit. Andreiană, 2010, p. 391. 
înaintea lui Andrei şi Filip cu privire la preamărirea $\mathrm{Sa}$ prin moarte, putem citi: „Atunci a venit un glas din cer: Şi L-am preaslăvit şi iarăşi Îl voi preaslăvi" (In. 12, 28). Teologul catolic iezuit Xavier Leon-Dufour, făcând referire la versetul precedent, consideră că acesta dă mărturie despre evenimentul biblic petrecut pe muntele Tabor - Transfigurarea Domnului: „Lăsând la o parte decorul teofanic, evenimentul este redus la esenţial: vocea din cer proclamă slava lui Iisus”; în plus ,unul dintre martorii privilegiaţi, Ioan, transpune amintirile sale despre acest eveniment într-o situaţie diferită de cea a mărturiilor sinoptice, dar potrivit unei înţelegeri a tainei care, departe de a-i altera substanţa, împlineşte semnificaţia ei profundă"’3.

A. M. Ramsey crede şi el că Schimbarea la Faţă este omisă în limbajul ioaneic pentru că Evanghelia a patra este o teofanie continuă: „slava nu este rezervată niciunui episod particular: ea se întinde de-a lungul întregii istorii evanghelice"4. Autorul expune un fapt inedit, arătând legătura dintre două evenimente importante din viaţa Mântuitorului - Schimbarea la Faţă şi rugăciunea din gradina Ghetsimani, înainte de Patima Sa. Acestea nu sunt prezentate de Sfântul Ioan în Evanghelia Sa. Evenimentele nu sunt descrise aici, nu pentru că Sfântul Ioan nu a participat la desfăşurarea lor, ci pentru faptul că el a descoperit cel mai bine sensurile profunde ale acestor fapte minunate ${ }^{5}$.

Dacă interpretarea versetului 28 din capitolul al 12-lea al Evangheliei după Ioan în sensul unei aluzii la Schimbarea la Faţă rămâne ipotetică, episodul este menţionat limpede în a doua epistolă sobornicească a Sfầntului Apostol Petru (1, 16-18). Dar şi aici este redus la esenţial: ,am văzut slava Lui cu ochii noştri. Căci El a primit de la Dumnezeu-Tatăl cinste şi slavă atunci când, din înălţimea slavei, un glas ca acesta a venit către El: «Acesta este Fiul Meu Cel iubit, întru Care am binevoit». Şi acest glas noi 1-am auzit,

${ }^{3}$ Citat de Vasile MANEA, Întâlnirea cu Dumnezeu exprimată în icoana Schimbării la Faţă, Cluj-Napoca, Edit. Patmos, 2006, p. 42.

${ }^{4}$ Arthur Michael RAMSEY, The Glory of God and the Transfiguration of Christ, Oregon, Wipf Stock Eugene, 2009, p. 123.

${ }^{5}$ Ibidem, p. 123-124. 
pogorându-se din cer, pe când eram cu Domnul în muntele cel sfânt”. Aici este descris evenimentul Schimbării la Faţă, folosinduse fraze (texte) din evangheliile Sfinţilor Matei şi Luca.

De asemenea, se observă folosirea unui limbaj mai onorific.

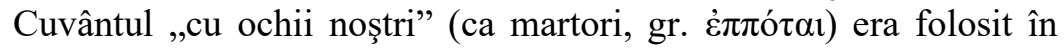
trecut la iniţierile în misteriile eleusiene. Cuvântul întrebuinţat pentru definirea „slavei” ( $\delta$ ó $\xi \alpha)$, de altfel, apare foarte rar în limbajul neo-testamentar. Prezentarea acestui eveniment în a doua epistolă a Sfântului Apostol Petru arată importanţa Schimbării la Faţă în iconomia mântuirii şi dă mărturie pentru Parusia Domnului la sfârşitul veacurilor ${ }^{6}$.

Mai mulţi exegeţi contemporani confirmă faptul că Schimbarea la Faţă a Domnului ocupă în Evangheliile sinoptice un loc central şi că episodul are legătură directă cu cel din relatarea imediat anterioară şi împlineşte făgăduinţa făcută acolo: „Adevărat grăiesc vouă: Sunt unii din cei ce stau aici care nu vor gusta moartea până ce nu vor vedea pe Fiul Omului, venind în împărăţia Sa” (Mt. 16, 28, $c f$. Mc. 9, 1) ${ }^{7}$.

Potrivit lui Benoit Standaert, revelaţia de pe muntele Tabor constituie în limbajul marcian, punctul central al textului întregii Evangheliii ${ }^{8}$. La rândul său, Pierre Bonuard spune că, în limbajul mateian, Schimbarea la Faţă se află în centrul naraţiunii evanghelice ${ }^{9}$. Din nou, A. M. Ramsey confimă importanţa Transfigurării prin cuvintele:

„Schimbarea la Faţă pare să se situeze în cadrul vieţii publice a lui Iisus la limita a doi versanţi... Chiar în puctul ei culminant, relatarea aminteşte de Botez: o voce din cer mărturiseşte filiaţia, iar prin cei trei ucenici care sunt martori ai unui moment decisiv în relaţia lui Iisus cu DumnezeuTatăl, ea se înrudeşte cu agonia din Ghetsimani"10.

\footnotetext{
${ }^{6}$ Ibidem, p. 125-126.

${ }^{7}$ Vasile MANEA, op. cit., p. 43.

${ }^{8}$ Ibidem, p. 43-44.

${ }^{9}$ Ibidem, p. 44.

${ }^{10}$ Arthur Michael Ramsey, op. cit., p. 123.
} 
În Evanghelia după Marcu, Schimbarea la Faţă vine după opt capitole pregătitoare, imediat după mărturisirea lui Petru - „Tu eşti Hristos, Fiul lui Dumnezeu Celui viu!” - şi după vestirea Patimilor. Evenimentele din următoarele opt capitole sunt împlinirea acestei profeţii a lui Hristos, Care trebuie Să pătimească şi Să moară, dar Care Va învia a treia $\mathrm{zi}^{11}$.

În niciun alt loc, în afară de expunerea evenimentelor din Săptămâna Patimilor, Sfântul Marcu nu expune un interval de timp, aşa cum se relatează în paragraful ce descrie Schimbarea la Faţă a Domnului - „după şase zile”. Mulţi cercetători au văzut în numărul şase un simbolism aparte. Astfel, sunt puse în lumină evenimente vetero-testamentare care sunt legate de acestă cifră: Moise a stat şase zile cuprins de nor pe muntele Sinai, înainte de întâlnirea cu Dumnezeu; un preot de la templu s-a curăţit (purificat) timp de şase zile înainte de o sărbătoare religioasă $\breve{a}^{12}$.

Episodul Schimbării la Faţă nu poate fi separat de cuvintele pe care Mântuitorul tocmai le-a spus ucenicilor Săi şi de făgăduinţa făcută în Cezareea lui Filip (Mt. 16, 28 şi Mc. 9, 1). Dimpotrivă, episodul este strâns legat de această profeţie şi reprezintă împlinirea ei. De altfel, Evanghelistul Luca chiar precizează: „Iar după cuvintele acestea, ca la opt zile" $(9,28)$. Sfântul Grigorie Palama spune că, în această făgăduinţă, Domnul numea ,împărăţia Sa" tocmai lumina Schimbării Sale la Faţă ${ }^{13}$. Această interpretare o regăsim şi în Omilia a doua la praznicul Transfigurării a Patriarhului Proclu al Constantinopolului. Astfel, el confirmă faptul că numeroşi dintre vechii exegeţi, nu se ştie pentru care motiv, aplicau aceste cuvinte Stăpânului pentru cea de-a doua înălţare întru slavă. Tocmai de aceea ei asigurau că evanghelistul Ioan nu gustase moarte, dar el aştepta înălţarea Stăpânului întru slavă, pentru că Domnul a exclamat cu multă emfază: „Există unii aici care nu gustă

${ }^{11}$ Vasile MANEA, op. cit., p. 44.

12 Arthur Michael RAMSEY, op. cit., p. 113. Despre simbolismul cifrei 6, vezi şi: Alexandru PRELIPCEAN, „Gematria ebraică - paradigmă ermineutică a Sfintei Scripturi. Studiu de caz: cifrele 1-7 în cartea Facere", în Studii Teologice 2 (2008), p. 177-212 (aici p. 201-206).

${ }^{13}$ Vasile MANEA, op. cit., p. 45. 
moartea, care nu L-au văzut pe Fiul Omului venind în împărăţia Sa" (Mt. 16, 28). Dar aici, care este sensul? Nu trebuie să joci cu viclenie, trebuie să spui adevărul şi, mai ales acum, să cauţi.

Aici deci, nu este a doua înălţare în glorie despre care se vorbeşte, ci de transfigurarea de pe munte. Şi în sfârşit, în timp ce era transfigurat pe munte, Hristos Stăpânul a arătat discipolilor Săi slava împărăţiei dumnezeieşti nevăzute ${ }^{14}$.

Există multe similitudini între cele trei pericope care relatează Schimbarea la Faţă în Evangheliile sinoptice, dar există, de asemenea, diferenţe care arată că fiecare Evanghelist are propria sa teologie cu privire la acest eveniment. Evanghelistul Matei este singurul care menţionează că, auzind glasul Tatălui, ucenicii au căzut cu faţa la pământ, dar adaugă imediat că Iisus s-a apropiat de ei, spunându-le: „Sculaţi-vă şi nu vă temeţi” $(\text { Mt. 17, 7) })^{15}$.

Sfântul Luca îi prezintă pe cei trei apostoli ,îngreuiaţi de somn" ( $\beta \varepsilon \beta \alpha \rho \eta \mu \varepsilon ́ v o \imath$ v̌ $\pi v \omega)$, aşa cum îi vedem de altfel reprezentaţi în unele icoane al Schimbării la Faţă, precizând şi el că „s-au spăimântat când au intrat în nor şi glas s-a făcut din nor, zicând: Acesta este Fiul Meu cel iubit, de El să ascultaţi” (Lc. 9, 34-35). Apostolul Luca este singurul dintre evanghelişti, care face referire la posibilitatea ca evenimentul de pe Tabor să se fi petrecut noaptea. Acest lucru este justificat de către unii cercetători prin realitatea că este posibil ca Hristos împreună cu apostolii să fi coborât muntele când se lăsa seara ${ }^{16}$.

Evanghelia după Luca este singura în care se menţionează prezenţa dialogului dintre Iisus şi cei doi prooroci, Moise şi Ilie, dialog ce avea ca subiect patimile Domnului: „vorbeau despre

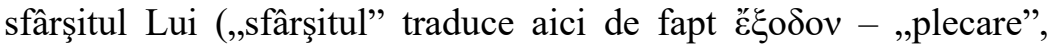
„,ieşire”), pe care avea să-L împlinească la Ierusalim (Lc. 9, 31). Domnul împlineşte la Ierusalim ceea ce Moise a prefigurat,

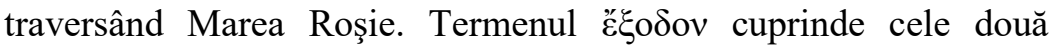

14 Dom Michel Coune, obs. Moine de Sainte-André-lez-Bruges, Joie de la Transfiguration, D’Après les Pères D’Orient (Spiritualite Orientale, 39), Paris, Abbaye de Bellefontaine, 1985, p. 83.

15 Vasile MANEA, op. cit., p. 45.

${ }^{16}$ Arthur Michael RAMSEY, op. cit., p. 112. 
noţiuni de moarte şi înălţare, pentru că Sfântul Luca nu prezintă niciodată moartea lui Iisus separat de moartea Sa $\left(c f\right.$. Lc. 9, 51) ${ }^{17}$.

Elementul care dă o notă profundă evenimentului de pe Muntele Tabor este faptul că aspectul feței lui Hristos s-a schimbat ,în timp ce se ruga" ( $c f$. Lc. 9, 29) ${ }^{18}$. Această relaţie între rugăciunea lui Iisus şi Schimbarea la Faţă - remarcă Frederic Godet - este exprimată la Sfầntul Evanghelist Luca prin prepoziţia $\dot{\varepsilon} v$, care indică, totodată, simultaneitatea şi relaţia cauză-efect. Părinţii Bisericii afirmă că Mântuitorul se ruga pentru a le arăta ucenicilor că rugăciunea este calea pe care omul poate ajunge să participe la Slava lui Dumnezeu ${ }^{19}$.

Ca fapt istoric, momentul solemn al transfigurării Mântuitorului pe Tabor s-a petrecut la mijlocul activităţii Sale mesianice, după ce săvârşise multe semne şi minuni, care adevereau faptic mărturiile profeţilor şi confirmau originea şi puterea Sa dumnezeiască. Deşi evenimentul sărbătorit are o motivaţie pur teologică, fiind menit să schimbe radical concepţia ucenicilor Săi despre mesianitatea Sa şi să orienteze sensul spiritual al vieţii umane, el are şi o fundamentare biblică vechi testamentară ca şi celelalte sărbători mari. Aceasta, datorită faptului că, în Persoana Fiului lui Dumnezeu, s-au împlinit toate făgăduinţele şi prezicerile profetice ale Vechiului Testament, iar evenimentele istorice legate de lucrarea providenţială săvârşită de Dumnezeu în viaţa poporului ales şi-au găsit împlinirea şi realizarea lor deplină în Noul Testament (Mt. 5, 17).

Minunea Schimbării la faţă are loc în contextul prăznuirii serbării iudaice a corturilor, care dura şapte zile (începând din ziua a 15-a a lunii a şaptea), prima şi a opta fiind zile de odihnă (Lev. 23). Însuşi cadrul natural al desfăşurării minunii este încărcat de rezonanţe şi semnificaţii veterotestamentare, după relatările evangheliştilor: norul luminos care îi umbrea pe Apostoli ca un cort, glasul lui Dumnezeu Tatăl din cer, prezenţa celor doi mari prooroci, Moise şi

${ }_{17}^{17}$ Ibidem, p. 113.

18 Andreas Andreopoulos, Metamorphosis. The Transfiguration in Byzantine Theology and Iconography, St. Vladimir's Seminary Press, New York, Crestwood, 2005, p. 45.

${ }^{19}$ Vasile MANEA, op. cit., p. 42-46. 
Ilie şi propunerea Sfântului Apostol Petru de a se construi cele trei colibe, sunt indicii care întăresc ipoteza că episodul Schimbării la Faţă s-a petrecut sub influenţa cinstirii sărbătorii corturilor ${ }^{20}$. Oscilaţia însăşi a relatărilor sfinţilor evanghelişti ne sugerează tocmai intervalul de timp în care se extindea sărbătoarea corturilor, ziua a opta având o semnificaţie cu totul specială, căci era zi de odihnă şi anticipa ,ziua cea mare a învierii, când va avea loc serbarea Cortului nostru dedicată Domnului" ${ }^{21}$.

$\mathrm{Cu}$ privire la aparenta diferenţă ce apare între relatările Evangheliştilor cu privire la timpul Schimbării la Faţă, Sfântul Ioan Damaschin scoate în evidenţă simbolismul zilelor:

„«Şi după şase zile» binevestesc dumnezeieştii evanghelişti Matei şi Marcu, pe când Luca cel preaînţelept zice: «Iar după cuvintele acestea, au trecut ca la opt zile». Într-adevăr şi pe drept sunt menţionate şi opt şi şase zile de către propovăduitorii adevărului. Că nu este niciun dezacord în ceea ce s-a spus, ci este vădit acordul rostit de Duhul Însuşi; căci nu ei sunt cei ce vorbesc, ci Duhul lui Dumnezeu vorbind în ei. Aşadar, cei care au spus după şase zile au lăsat la o parte extremele, adică pe prima şi pe ultima zi, numărând doar zilele cele din mijloc; pe când cel care a numărat opt zile le-a numărat şi pe unele, şi pe altele împreună. Iar şase este luat ca primul număr desăvârşit. Căci este alcătuit de două ori din el însuşi: or, trei este doimea acestuia, doi este treimea, şi unu este şesimea lui, şi, adunate fiind, îl fac desăvârşit" 22 .

In extensio ,opt este tip atât al viitorului, cât şi al veacului. Căci viaţa prezentă durează şapte veacuri, prin cel de-al optulea este

${ }^{20}$ Andreas ANDREOPOUlos, op. cit., p. 57.

${ }^{21}$ Metodiu DE Olimp, Banchetul sau despre castitate, trad. Constantin Corniţescu (Părinţi şi Scriitori bisericeşti, 10), Bucureşti, Edit. Institutului Biblic şi de Misiune al Bisericii Ortodoxe Române, 1984, p. 103-104.

22 Sfântul IOAN DAMASCHIN, „Cuvânt la Schimbarea la Faţă a Domnului şi Mântuitorului nostru Iisus Hristos", în vol. Cuvântări la sărbători împărăteşti, la sărbători ale Maicii Domnului şi la Sfinţi, trad. Gabriel Mândrilă şi Laura Mândrilă, Bucureşti, Edit. Institutului Bibilic şi de Misiune Ortodoxă, 2010, p. 84. 
vestită viaţa viitoare" 23 , aşa cum a spus marele teolog Grigorie, tâlcuind apoftegma solomonică: împarte o bucată în şapte, adică viaţa viitoare. A trebuit ca într-a opta zi să fie descoperite celor desăvârşiţi cele ale veacului al optulea. Aşa cum spunea cu adevărat dumnezeiescul şi grăitorul de cele sfinte Dionisie, că aşa se va arăta Stăpânul slugilor Sale desăvârşite, aşa cum a fost văzut pe Tabor de către apostoli ${ }^{24}$.

Mântuitorul Îşi dezvăluie slava dumnezeirii Sale în clipele convorbirii tainice şi minunate ale sufletului cu Dumnezeu care este rugăciune. Iisus se roagă şi rugăciunea Sa capătă un nimb strălucitor de dumnezeire. Chipul feţei Sale a strălucit ca soarele, iar veşmintele Sale s-au făcut albe ca lumina. Hainele Sale luminoase preînchipuie firea omenească a lui Iisus, iar cele două lumini semnifică cele două firi ale Sale: Ziditor şi om, cer şi pământ, iubire şi mântuire ${ }^{25}$. Sfântul Grigorie Palama spune că „lumina aceasta este mai presus nu numai de simţuri, ci şi de toate cele ce sunt şi că această vedere este mai presus de fïre"26. Lumina aceasta este slava naturii dumnezeieşti. Ea izvora din fiinţa Sa divină, dar nu se identifica cu ea: „A dat firii omeneşti slava dumnezeirii, dar nu firea. Altceva este, aşadar, natura lui Dumnezeu şi altceva slava Lui, deşi sunt nedreptăţite între ele"27. Această lumină necreată este ,miezul, substanţa şi frumuseţea veacului ce va să fie. Ea este singura lumină adevărată, eternă, neschimbată, prin care devenim şi noi lumină, ca nişte fii ai luminii" 28 .

23 Ibidem, p. 85.

${ }^{24}$ Sfântul IOAN DAMASCHIN, op. cit., p. 85.

25 Vasile Miron, Sărbătorile împărăteşti cu dată fixă în cinstea Mântuitorului. Istoricitatea, semnificaţia şi importanţa lor liturgică, religioasă şi etnografică, Bucureşti, Edit. Paideia, 2010, p. 175.

${ }^{26}$ Sfântul Grigorie PALAma, Despre lumina sfântă, în vol. Filocalia sau Culegere din Scrierile Sfinţilor Părinţi care arată cum poate omul curăţi, lumina şi desăvârşi, trad. Dumitru Stăniloae, Bucureşti, Edit. Institutului Biblic şi de Misiune al Bisericii Ortodoxe Române, 1977, p. 293.

${ }^{27}$ Ibidem, p. 283.

${ }^{28}$ Dumitru StăniloAe, Viaţa şi învăţătura Sfântului Grigorie Palama, Bucureşti, Edit. Scripta, 1993, p. 58. 


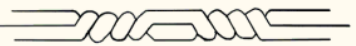

\section{Istoricul sărbătorii}

Sărbătoarea Schimbării la Faţă (6 august) este considerată a fi o sărbătoare mai nouă în cadrul sinaxarelor bisericeşti. Totuşi, mărturii despre cinstirea evenimentului minunat petrecut pe muntele Tabor, avem chiar din secolul al IV-lea. Se pare că sărbătoarea a fost la început aniversarea anuală ( $\dot{\varepsilon} \gamma \kappa \alpha i v v 1 \alpha$ ) a sfinţirii celei dintâi dintre aceste două biserici, biserică zidită în secolul al IV-lea de către Sfânta Elena, mama Sfântului Împărat Constantin cel Mare, pe muntele Taborului. Aşadar, originea acestei sărbători este puţin mai târzie decât a celorlalte praznice împărăteşti, coborând spre prima jumătate a secolului al V-lea.

Istoricul Eusebiu de Cezareea, în Historia Ecclesiastica, oferă informaţii preţioase despre libertatea religioasă de care se bucura Biserica în secolul al IV-lea. Acesta face referire la tradiţia vremii de a se construi biserici şi de a se prăznui ziua sfinţirii acestora: „O privelişte plăcută şi dorită de toţi ne-a fost hărăzit să vedem: praznice de întemeiere de biserici prin toate oraşele precum şi târnosiri ale locaşurilor nou construite"29.

Despre existenţa bisericii de pe mutele Taborului, avem mărturii din partea istoricului Nichifor Calist Xanthopol. Acesta expune faptul că Sfânta Împărăteasă Elena a ridicat o biserică pe Muntele Tabor, pe care a înzestrat-o cu multe daruri. De asemenea, în timpul conducerii Imperiului bizantin de către Sfântul Constantin, a fost construită pe Tabor o scară de marmură, pentru a face cât mai accesibil traseul până la mănăstirea de pe vârful muntelui $^{30}$. În urma excavărilor făcute de călugării franciscani pe muntele Tabor, s-a scos la lumină existenţa a două biserici aici, una construită de către cruciaţi, iar cealaltă datând probabil, din secolele al IV-lea sau al V-lea ${ }^{31}$.

${ }^{29}$ Eusebiu de CeZareeA, Istoria Bisericească, X, trad. Teodor Bodogae (Părinţi şi Scriitori bisericeşti, 12), Bucureşti, Edit. Institutului Biblic şi de Misiune al Bisericii Ortodoxe Române, 1987, p. 363.

${ }^{30}$ Arthur Michael RAMSEY, op. cit., p. 128.

${ }^{31}$ Ibidem. 
O informaţie preţioasă despre atestarea serbării Schimbării la Faţă a Domnului o găsim menţionată de către unul din cititorii jurnalului pelerine Egeria. Acesta arată faptul că pelerina Aeteria a participat la comemorarea evenimentului de pe Tabor, în anul 385. Cititorul Valere de Galice relatează faptul că Egeria

„,nu s-a mulţumit să parcurgă aproape toate colţurile lumii, ci a avut grijă să se urce şi pe piscurile unor munţi înalţi... apoi, pe vârful muntelui înalt al Taborului unde Domnul, însoţit de Moise şi Ilie, S-a arătat ucenicilor Săi, întru slavă"32.

O răspândire mai deosebită a luat-o sărbătoarea începând din secolele IV-V. Aceasta rezultă din faptul că ea a fost pusă încă din această perioadă alături de marile sărbători împărăteşti. Astfel, un vechi adagiu tradiţional creștin înşiră sărbătorile împărăteşti în ordinea următoare: Bunavestire, Naşterea Domnului, Întâmpinarea, Schimbarea la Faţă, Învierea lui Lazăr, Duminica Stâlpărilor, Răstignirea, Învierea, Inălţarea Domnului şi Pogorârea Duhului Sfânt ${ }^{33}$.

Anticiparea sărbătorii se vede apoi în multe predici ţinute în această zi chiar în secolul al IV-lea. În acest sens sunt de amintit omiliile celebrilor predicatori ai vremii: Sfântul Ambrozie al Milanului, Sfântul Chiril al Alexandriei ${ }^{34}$, Sfântul Efrem Sirul şi Sfântul Ioan Gură de Aur.

Vorbind despre semnificaţia praznicului, Sfântului Ioan Gură de Aur zice:

${ }^{32}$ M. VON EsBroEK, „Une homelie georgienne anonyme sur la Transfiguration”, în Orientalia Christiana Periodica 46 (1980), p. 420.

33 Dumitru MocA, „Sărbătoarea Schimbării la Faţă a Domnului, consideraţii istorico-liturgice", în Altarul Banatului 7-9 (2001), p. 38-39.

${ }^{34}$ Pentru Ambrozie al Milanului, Expositio Evangelii Secundam Lucam VII.6-20, vezi: Gabriel Tissot (ed.), Ambroise de Milan, Traité sur l'Évangile de S. Luc, tome I (Sources Chrétiennes 45), Paris, Éditions du Cerf, 1976, p. 10-16, iar pentru Chiril al Alexandriei, Omilia 51, vezi: R. M. TonneAu (ed.), S. Cyrilli Alexandrini Commentarii in Lucam: Pars Prior (Corpus Scriptorum Christianorum Orientalium, 140: Scriptoris Syri 70), Louvain, Dubecq, 1953, p. 119-122. 
„Există un al treilea temei pentru care Moise şi Ilie s-au arătat alături de Hristos. Care este acela? Pentru ca Apostolii să cunoască că El are puteri peste moarte şi viaţă; de aceea a trebuit să se înfăţişeze lângă dânsul Moise şi Ilie cel ce încă nu era mort. Un alt temei ne dă evanghelistul Luca spre a arăta mărimea crucii şi pentru a îmbărbăta şi ridica duhul lui Petru şi al celorlalţi Apostoli care încă se temeau de patimă. Adică, după relatarea lui Luca, Moise şi Ilie nu au tăcut, ci au vorbit despre mărirea Lui care avea să se plinească la Ierusalim... Petru ştia că Domnul va merge la ierusalim, după dojana aceea cu cuvintele: «fugi de la Mine satana» (Mt. 16, 23), el nu a mai cutezat să zică către Domnul: milostiv fii mie Doamne. De aceea, rosteşte el aceeaşi idee cu alte cuvinte: bine este nouă să fim aici. Căci muntele şi latura aceea nelocuită I se păreau lui a da siguranţă şi încă mai sigur I se părea lui dacă Domnului s-ar duce la Ierusalim, ci de-a pururea ar rămâne acolo. De aceea vorbeşte el de corturi" ${ }^{\prime \prime}$.

Un aspect determinant pentru importanţa acordată de Biserică muntelui Tabor şi implicit sărbătorii Schimbării la Faţă a Domnului, îl reprezintă existenţa scaunului episcopal de Tabor. Despre unul dintre episcopii titulari ai acestuia aflăm că a participat la cel de al V-lea Sinod Ecumenic, care a avut loc la Constantinopol în anul $553^{36}$.

Din secolul al V-lea avem cuvântări festive în cinstea sărbătorii de la Proclu, patriarhul Constantinopolului, patriarhul Chiril al Alexandriei şi papa Leon cel Mare. Cel din urmă mare predicator, arată care este înţelesul tainic al evenimentului de pe muntele Tabor:

„Scopul principal al Schimbării la Faţă era acela de a smulge din inima ucenicilor scandalul crucii şi umilinţa patimii

35 Gh. Pletosu, „Cuvânt la 6 august. Schimbarea la Faţă a Domnului”, în Revista

Teologică 3 (1909), p. 337-341.

${ }^{36}$ Arthur Michael RAMSEY, op. cit., p. 128. 
acceptate de bună voie, să nu-i demoralizeze pe cei în faţa cărora avea să-şi arate demnitatea tainică împărătească. Dar El nu se gândea mai puţin să pună temelia speranţei Bisericii sale; astfel încât trupul tainic al lui Iisus Hristos, cunoscând acea transformare care îi era rezervată, fiecare din mădularele sale, să poată avea nădejdea că va avea parte de mărirea de care Hristos, capul Bisericii, strălucise de mai înainte" ${ }^{37}$.

Michele Coune, cercetând o omilie georgiană anonimă, care face referire la praznicul Schimbării la Faţă, datează acest text întro perioadă puţin anterioară secolului al VI-lea. Autorul anonim pomeneşte data de 6 Lous ca zi de cinstire a evenimentului deosebit petrecut pe muntele Tabor. În Antiohia, luna Lous corespunde lunii august; cu toate acestea, la Ierusalim nu există o corespondenţă exactă între luna Lous şi luna august ${ }^{38}$.

Din secolul al VI-lea, avem un comentariu despre Schimbarea la Faţă a Domnului, care aparţine lui Timotei al Ierusalimului. Acesta aduce în discuţie legătura strânsă care există între Cruce şi evenimentul minunat ce a avut loc pe muntele Tabor ${ }^{39}$.

Sărbătoarea Schimbării la Faţă o găsim indicată şi într-un calendar liturgic local al Ierusalimului din secolul al VII-lea, în sinaxarele constantinopolitane şi în alte cărţi liturgice manuscrise greceşti unde apare tot mai des pe la începutul secolului al VIIIlea ${ }^{40}$. Sfântul Andrei Criteanul, vieţuitor în acest secol, ne-a lăsat o frumoasă predică festivă la această sărbătoare. În cuvântul său, „marele povăţuitor al Cretei”, tratează Schimbarea la Faţă „,nu numai din punct de vedere dogmatic, ci şi în sens de sărbătoare reală şi solemnă a Bisericii" ${ }^{4}$.

${ }^{37}$ Dumitru MocA, art. cit., p. 39.

${ }^{38}$ Dom Michel Coune, op. cit., p. 10.

39 Kenneth Stevenson, Rooted in Detachment.Living the Transfiguration, Michigan, Cistercian Publications, 2007, p. 9. Vezi: Timothei Antiocheni, In Crucem et in Transfigurationem, $P G$ 86, 255A-266B.

40 Ene BranişTe, Liturgica generală, Bucureşti, Edit. Institutului Biblic şi de Misiune al Bisericii Ortodoxe Române, 1993, p. 167.

${ }^{41}$ Petru LeBeDEw, Liturgica sau explicarea serviciului divin, trad. Nicolae Filip, Bucureşti, 1899, p. 309. 
După afirmaţia lui Nicon din Muntenegru şi a patriarhului Nicolae al III-lea al Constantinopolului din secolele XI-XII, în Răsărit, sărbătoarea ar fi fost ,instituită" de împăratul bizantin Leon înţeleptul, ceea ce trebuie înţeles în sensul generalizării oficiale a sărbătorii deja existentă mai dinainte care nu era însă sărbătorită pretutindeni, deoarece ea cădea în Postul Adormirii Maicii Domnului ${ }^{42}$.

În secolul al VIII-lea, importanţa praznicului este mai bine conturată prin faptul că marii imnografi, Sfântul Ioan Damaschinul şi Sfântul Cosma de Maiuma, compun imne pentru rânduiala lui liturgică ${ }^{43}$. Sfântul Ioan Damaschin este cel care alcătuieşte canonul zilei de 6 august $^{44}$ - o remarcabilă creaţie teologică, care reflectă învăţătura despre cea de a doua Persoană a Sfintei Treimi, Dumnezeu-Omul Iisus Hristos. Andre Guillow afirmă că menţionarea fixă a Schimbării la Faţă a Domnului, apare la Constantinopol abia în secolul al X-lea, în timp ce V. Grumel consideră că această sărbătoare datează cel puţin de la începutul secolului al VIII-lea, la începutul secolului al X-lea fiind instituită „o solemnitate liturgică pentru sărbătoarea care exista deja" 45 .

În Apus, sărbătoarea Schimbării la Faţă, deşi serbată sporadic încă de prin secolul al VII-lea era privită încă ca o inovaţie. În lucrarea sa, De statu Domus Dei, Photo de Prum, scriitor şi cleric din dieceza de Trier (secolele XI-XII), notează:

„Ne mirăm foarte că, în vremea noastră, unele mănăstiri au găsit cu cale să inventeze unele sărbători noi... Pentru care motiv, ne-am pus să sărbătorim aceste sărbători, adică a Sfintei Treimi şi a Schimbării la Faţă a Domnului”"46.

${ }^{42}$ Dumitru MocA, art. cit., p. 39-40.

${ }^{43}$ Ibidem.

${ }^{44}$ Petre VinTILESCU, Despre poezia imnografică din cărţile de ritual şi cântarea bisericească, Cluj-Napoca, Edit. Partener, ${ }^{2} 2006$, p. 89-90.

45 Vasile MANEA, Intâlnirea cu Dumnezeu exprimată în icoana Schimbării la Faţă, Cluj-Napoca, Edit. Patmos, 2006, p. 75-76.

46 „Miramur, quod nostro nonnulli in Monasteriis novas celebritates inducant. Quare? An patribus dictiores? Quae igitur ratio celebrandi festum Trinitatis et Transfigurationis Christi”. Vezi: Dr. Vasile Mitrofanovici, Prelegeri 
Schimbarea la Faţă se prăznuia de multă vreme în a doua duminică din Postul Mare. Sărbătoarea de la 6 august apare în Spania de-abia în mijlocul secolului al IX-lea şi mult timp a rămas necunoscută, în ciuda eforturilor centrului de la Cluny de a o propaga în secolul al XII-lea. Se pare că aici sărbătoarea s-a generalizat mult mai târziu, prin hotărârea luată de papa Calist al III-lea de a consacra definitiv această sărbătoare, drept mulţumire lui Dumnezeu pentru biruinţa câştigată de oştile creştine asupra turcilor la Belgrad, în anul 1465, în care un rol hotărâtor 1-a avut Sfântul Ioan Capistran. Cum se ştie, lupta a avut loc la 22 iulie 1456, iar vestea victoriei a ajuns la Roma la 6 august, motiv pentru care sărbătoarea a fost fixată şi aici la această dată în consens cu tradiţia bisericească universală. ${ }^{47}$ Acest eveniment este menţionat şi în cercetările lui Ene Branişte, cu adaosul că sărbătoarea era cinstită sporadic, în Apus, încă din secolul al VII-lea ${ }^{48}$.

Spre deosebire de Răsăritul creştin, Apusul consideră Schimbarea la Faţă o sărbătoare secundară (fără octostih) ${ }^{49}$. În Biserica Armeană, praznicul Schimbării Domnului la Faţă se bucură de o deosebită solemnitate liturgică, şi pentru acest motiv, atunci când cade într-una din zilele de rând de peste săptămână, prăznuirea ei se amână pentru duminica viitoare, iar în ajun se posteşte ${ }^{50}$. La armeni, evenimentul minunat de pe Tabor este prăznuit în a şaptea duminică după sărbătoarea Pogorârii Duhului Sfânt ${ }^{51}$. După unii liturgişti, Praznicul acesta ar fi înlocuit o veche sărbătoare păgână a zeiţei Diana. Rânduiala liturgică a Praznicului prevede ca să fie binecuvântată în această zi pârga de struguri, obicei foarte vechi menţionat încă din timpul Sinodului Trulan, prin canonul 28. În

academice despre Liturgica Bisericii dreptcredincioase răsăritene, Cernăuţi, 1909, p. 132.

${ }^{47}$ Philippe Rouillard, Les fetes chretiennes en Occident, Paris, Les Éditions du Cerf, 2003, p. 127.

${ }^{48}$ Ene BRANIŞTE, op. cit., p. 167.

${ }^{49}$ Leonid UsPENSKY, Vladimir UsPensKy, Călăuziri în lumea icoanei, trad. Anca Popescu, Bucureşti, Edit. Sofia, 2003, p. 228.

${ }^{50}$ Lucian FARCAȘIU, ,,Teologia imnografică a Praznicului Schimbării la Faţă a lui Hristos", în Teologia 3 (2005), p. 104-106.

${ }^{51}$ Arthur Michael RAMSEY, op. cit., p. 128. 
Biserica Rusiei în această zi se face pomenirea generală a morţilor şi mai ales a eroilor căzuţi pentru apărarea patriei ${ }^{52}$.

\section{Teologia imnografică a sărbătorii Schimbării la Faţă}

\section{a) perspectiva tipiconală}

Îndrumările din Mineiul pe luna August, reprezintă sinteza tradiţiei şi spiritualităţii răsăritene cu privire la modul cinstirii sărbătorii Schimbării la Faţă. Aici întâlnim, desigur, atât indicaţii tipiconale, cât şi aspecte diferite ale praznicului.

Astfel, în prologul din Mineiul pe luna August, din ziua a şasea, înainte de vecernia mică, găsim prima îndrumare tipiconală: „Dacă se va întâmpla Praznicul Schimbării la Faţă a lui Hristos în zi de duminică, nu se zice nimic ale Învierii, nici Evanghelia Utrenie nu se citeşte, ci toată slujba Praznicului se pune seara şi la Utrenie şi la Liturghie, neschimbată" 53 .

În cadrul Litiei, la binecuvântarea pâinilor, în semn deosebit de cinstire, se cântă troparul praznicului de trei ori: „Schimbatu-Teai la faţă, în munte, Hristoase Dumnezeule, arătând ucenicilor Tăi slava Ta, pe cât li se putea; strălucească şi nouă, păcătoşilor, lumina Ta cea pururea fiitoare, pentru rugăciunile Născătoarei de Dumnezeu, Dătătorule de lumină, slavă Ţie!" 54 .

La Utrenie, ca elemente specifice ale praznicului, amintim:

- Prochimenul şi stihul sunt de fapt citări din Psalmul 88, care fac referire la locul unde Hristos S-a Schimbat la Faţă;

- Evanghelia este specială, a praznicului, de la Sfântul Evanghelist Luca, capitolul al 9-lea, versetele de la 28 la 36.

În cadrul Sfintei Liturghii din ziua praznicului Schimbării la Faţă, antifoanele sunt speciale, ca zi de praznic împărătesc, având

\footnotetext{
52 Preot Ene BranişTe, op. cit., p. 167.

53 ***, Mineiul pe August, Bucureşti, Edit. Institutului Biblic şi de Misiune al Bisericii Ortodoxe Române, 2003, p. 68.

54 Ibidem, p. 71.
} 
stihuri care reflectă înţelesul teologic şi duhovnicesc al minunii de pe Muntele Tabor.

i. Astfel, Antifonul I se compune din repetarea formulei „Pentru rugăciunile Născătoarei de Dumnezeu, Mântuitorule, mântuieşte-ne pe noi", însoțită de stihuri, care sunt de fapt citări din Psalmii lui David (Ps. 42, 3; 56, 7, 13).

ii. Antifonul al doilea are în componenţa sa formula specială, care face referire la persoana Fiului lui Dumnezeu, precum şi la evenimentul biblic comemorat: „Mântuieşte-ne pe noi, Fiul lui Dumnezeu, Cel ce Te-ai schimbat la faţă în Muntele Taborului, pe cei ce-Ţi cântăm Ţie. Aliluia". Ca şi în cazul antifonului I, stihurile sunt tot citări din Psalmi (Ps. 67, 25; Ps. 16, 15; Ps. 103, 2). Antifonul al treilea este de fapt cântarea troparului Schimbării la Faţă.

iii. Apostolul şi Evanghelia sunt speciale, având legătură cu relatarea momentului minunat care a avut loc pe muntele Taborului. Apostolul este din Epistola a II-a sobornicească a Sfântului Apostol Petru (1, 10-17), iar Evanghelia este de la Sfântul Matei (17, 1-9).

iv. Axionul este cel al Praznicului (irmosul cântării a 9-a, din cadrul Canonului Utreniei: „Naşterea ta cea nestricată s-a arătat, căci Dumnezeu din pântecele tău a ieşit şi S-a arătat purtător de trup pe pământ şi cu oamenii a petrecut. Pentru aceasta, pe tine, de Dumnezeu Născătoare, toţi te mărim" ${ }^{55}$.

\section{b) Imnografii şi cuprins imnografic - generalităţi}

Ca la orice praznic împărătesc, formulările imnografice care împodobesc ritualul liturgic din data de 6 august, fac trimitere la evenimentul minunat ce s-a desfăşurat în muntele Taborului, când Domnul S-a schimbat la Faţă înaintea celor trei ucenici: Petru, Iacov şi Ioan.

Ideile din Evanghelie, despre Schimbarea la Faţă, ale Sfinţilor Părinţi şi ale scriitorilor bisericeşti, au pătruns în cântările cultice ale Bisericii Ortodoxe, scoţând în evidenţă semnificaţiile profunde ale Transfigurării. 
Imnografia praznicului se datorează, în cea mai mare parte, marelui imnograf Sfântul Ioan Damaschinul. Acesta, alături de fratele său vitreg Cosma Melodul, au compus imnele care alcătuiesc actualul canon al Utreniei din ziua de şase august, când Biserica Ortodoxă sărbătoreşte Schimbarea la Faţă a Domnului ${ }^{56}$.

Canonul întâi aparţine lui Cosma Melodul, iar cel de al doilea este alcătuirea Sfântului Ioan Damaschin. În forma lor originală, aceste creaţii poetice teologice poartă denumirea de acrostihuri şi se găsesc în colecţia Patrogia Graeca 96, 848-852 (Acrostihul Sfântului Ioan Damaschin) şi Patrogia Graeca 98, 492-497 (Acrostihul lui Cosma) ${ }^{57}$.

Imnele Sfântului Ioan Damaschin se regăsesc introduse în Mineiul pe luna August prin sintagma ,alt canon"58. Acestea reflectă întreaga teologie hristologică a marelui vieţuitor al Mănăstirii Sfântul Sava din Ţara Sfântă.

Alături de cei doi imnografi care au alcătuit Acrostihurile praznicului Schimbării la Faţă, un alt mare alcătuitor de imne contribuie la înfrumuseţarea slujbei Vecerniei Mari a zilei de 6 august. Acesta este Anatolie, despre a cărui identitate nu există o unanimitate între liturgişti. Marea majoritate a cercetătorilor îl consideră pe Anatolie, arhiepiscopul Tesalonicului, din secolul al IX-lea, adevăratul alcătuitor al imnurilor ce se regăsesc în Mineie ${ }^{59}$.

Astfel, toate cântările, care poartă amprenta teologiei Sfântului Ioan Damaschin, alcătuiesc o adevărată antologie melodică ce redă întreaga bogăţie de semnificaţii a transfigurării. Tradiţia Bisericii mărturiseşte lămurit în cântările ei realitatea teologică conform căreia Hristos-Mântuitorul este Dumnezeu adevărat:

„Cel ce a grăit cu Moise de demult prin închipuiri în Muntele Sinai, zicând: Eu sunt Cel ce sunt de-a pururea,

56 Vezi „Anexa B - Melozii, Imnografii şi Melurgii din cărţile de astăzi de slujbă bisericească" din Petre VINTILESCU, op. cit., p. 252.

${ }^{57}$ Dom Michel Coune, op. cit., p. 186.

58 ***, Mineiul pe August, p. 75.

${ }^{59}$ Petre VinTILESCU, op. cit., p. 119-120. 
astăzi, schimbându-Se la faţă în Muntele Taborului, înaintea ucenicilor, Şi-a arătat frumuseţea cea dintâi a chipului, Care a ridicat în Sine firea omenească" ${ }^{\circ 0}$.

Imnografii au surprins în minunea Schimbării la Faţă a Domnului şi puterea sfinţitoare a harului care duce la îndumnezeirea oamenilor: „Cela ce cu lumina Ta ai sfinţit toată lumea în munte înalt Te-ai schimbat la faţă Bunule, arătând ucenicilor puterea Ta, că mântuieşti lumea din călcarea poruncii... şi ai arătat ucenicilor tăi slava Dumnezeirii Tale" $"$. În aceeaşi armonie duhovnicească se încadrează şi irmosul al 2-lea, al Cântării a 9-a: „Întru slavă neapropiată, arătându-le negrăit peste muntele Taborului, Lumina cea necuprinsă şi nespusă, Raza Tatălui, a luminat făptura şi a îndumnezeit pe oamenii cei ce cântă: Binecuvântaţi toate lucrurile Domnului pe Domnul"62.

Schimbarea la Faţă a Domnului, prin lumina ei transformatoare, avea să lucreze treptat asupra Apostolilor, înlăturându-le spaima şi greutatea înţelegerii atât a misiunii lor, cât şi pe aceea a ridicării trupului omenesc, din stricăciune şi păcat la starea de îndumnezeire. Despre aceasta, Petru cel îndoielnic şi greu la înţelegere, după ce s-a luminat, a scris creştinilor: „v-aţi făcut părtaşi ai dumnezeieştii firi” (2 Pt. 1,4$)$, prin primirea harului divin în Sfintele Taine. În acest sens unele cântări, subliniază schimbarea firii omeneşti. „Schimbându-Se la faţă... a arătat frumuseţea chipului cea dintâi, ridicând întru Sine fiinţa omenească" (stihoavna Vecerniei). Acelaşi adevăr se regăseşte şi în stihoavna Vecerniei Mici: „Astăzi Hristos în muntele Taborului a schimbat firea lui Adam cea negrăită, luminând-o cu dumnezeiasca lucrare" ${ }^{63}$.

Sunt însă şi cântări care exprimă adevărate rugăciuni de cerere, sau de preamărire, precum: „Schimbatu-Te-ai la faţă în munte Hristoase Dumnezeule, arătând Ucenicilor Tăi slava Ta pe cât li se putea. Strălucească şi nouă păcătoşilor lumina Ta cea

\footnotetext{
60 ***, Mineiul pe August, Stihoavna de la Vecernie, Stihira I, p. 72.

${ }^{61}$ Ibidem, Stihira la Litie, p. 73.

62 Ibidem, p. 79.

${ }^{63}$ Ibidem, p. 72.
} 
pururea fiitoare. Pentru rugăciunile Născătoarei de Dumnezeu, Dătătorule de lumină, slavă Ție" (Troparul Schimbării la Faţă) ${ }^{64}$. Axionul sărbătorii reflectă profunzimea teologiei praznicului, dar în acelaşi timp reprezintă o rugăciune de cerere: „Măreşte sufletul meu pe Cel ce S-a schimbat la faţă pe muntele Tabor..."65.

\section{c) Intruparea Cuvântului - scop şi semnificaţii}

Textele liturgice ale Praznicului reflectă întreaga teologie hristologică a Sfântului Ioan Damaschin, care preamăresc atât importanţa Întrupării Fiului lui Dumnezeu, precum şi îndumnezeirea omului, ca şi scop ultim al acesteia. Hristos este plinirea Legii şi proorocilor şi Cel Care îşi călăuzeşte poporul spre contemplarea slavei Sale.

Prin minunea Schimbării la Faţă pe muntele Taborului, Mântuitorul Iisus Hristos este prezentat de Tatăl ceresc înaintea lumii, ca Fiu al Său. Arătarea slavei Sale dumnezeieşti, Îl descoperă pe Hristos ca Dumnezeu Întrupat, pentru mântuirea lumii: „Văzutu-Te-au în Tabor Moise şi Ilie, din Fecioară pruncă Dumnezeu Întrupat, pentru mântuirea oamenilor"66. Hristos, Cel ce stă pe muntele Taborului cu trupul, strălucind de slava dumnezeirii, arată acum faptul că în Persoana Sa, firea dumnezeiască şi firea omenească stă în unire. Unirea ipostatică a celor două firi (dumnezeiască şi omenească) în Persoana lui Hristos, reprezintă una din temele de bază ale teologiei Sfântului Ioan Damaschin. Despre acest adevăr dau mărturie mai multe texte liturgice din cadrul slujbelor ce ţin de slăvitul Praznic al Schimbării la Faţă. Astfel, în troparul 4, al cantării a 3-a, din Utrenia zilei de 6 august, citim: ,Dumnezeu desăvârşit fiind, Om desăvârşit S-a făcut cu toată Dumnezeirea amestecând unirea în faţa Sa. Pe acesta în două fiinţe L-au văzut Moise şi Ilie în muntele Taborului" ${ }^{67}$.

${ }^{64}$ Ibidem, p. 71.

65 Ibidem, p. 73.

66 ***, Mineiul pe August, Vecernia Mică, Stihoavnă, la Slavă... Şi acum..., p. 71.

${ }^{67}$ Ibidem, Utrenia, Canoanele, Canonul al II-lea, Cântarea a 3-a, troparul al 4-lea, p. 79. 
Scopul Întrupării Cuvântului Celui din veşnicie, este acela de a transfigura natura umană căzută, redându-i starea dumnezeiască dintru început: „Astăzi Hristos în Muntele Taborului, schimbând firea lui Adam cea întunecată, a îndumnezeit-o strălucind..." (Vecernie, 7 august, Stihirile Stihoavnei); „Firea omenească cea întinată curăţind-o cu apă şi cu foc, în trupul Tău ai arătat strălucirea acesteia, Mântuitorule, cu faţa Ta strălucind mai mult decât soarele, chipul slavei ce va să fie arătându-1" (primul canon al Înainteprăznurii, cântarea a $7-a)^{68}$.

Norul luminos care a acoperit muntele era semnul concret al prezenţei Duhului Sfânt în Legea Nouă a harului şi a adevărului, pe care urma să o instituie Stăpânul Hristos, adevăratul dătător al Legii, înaintea Căruia Moise şi Ilie se pleacă şi Îl recunosc ca Dumnezeu şi Ziditor: „Nor luminos Te-a luat, schimbându-Te la faţă în întunericul Legii, în care Moise şi Ilie fiind şi de preluminata slavă învrednicindu-se, către Dumnezeu au strigat: Tu eşti Dumnezeul nostru şi împăratul veacurilor"69.

Pe Tabor are loc prin excelenţă descoperirea Treimii celei nedespărţite, şi prezentarea Fiului lui Dumnezeu ca şi Stăpânitor al celor vii şi al celor adormiţi. Această idee este exprimată astfel în cântările preznicului:

„Cel ce este lumină mai înainte de soare, Hristos..., astăzi în muntele Taborului, cu taină chipul Treimii 1-a arătat..., că Sa schimbat la faţă înaintea ucenicilor... Cel ce stăpâneşte peste vii şi peste cei morţi şi pe cei mai mari dintre prooroci, pe Moise şi pe Ilie, i-a adus să mărturisească fără împotrivire Dumnezeirea Lui" "70.

Moise şi Ilie pe Tabor, dimpreună cu cei trei ucenici, nu au văzut fiinţa lui Dumnezeu, ci energia Sa divină, lumina cea necreată a Sfintei Treimi, care a îndumnezeit firea omenească a Mântuitorului ${ }^{71}$ :

${ }^{68}$ Vasile MANEA, op. cit., p. 80.

69 ***, Mineiul pe August, Slavă... Şi acum... de la Vecernia Mică, p. 71.

70 ***, Mineiul pe August, stihira a treia de la Litie, la Vecernia Mare, p. 75.

${ }^{71}$ Ibidem. 
„În acest munte suindu-Te, Mântuitorule, cu ucenicii Tăi, şi la faţă schimbându-Te, ai făcut firea lui Adam iarăşi a străluci, mutând-o în slava şi strălucirea dumnezeirii Tale. Pentru aceasta, strigăm către Tine: Făcătorule a toate, Doamne, slavă Ţie!"72.

Natura umană a lui Hristos este îmbrăcată în slavă dumnezeiască, „căci în El locuieşte, trupeşte, toată plinătatea Dumnezeirii” (Col. 2, 9): „Această natură face să apară dumnezeirea care este strălucirea comună a celor Trei Persoane. Natura umană a lui Hristos va servi drept prilej de manifestare a Sfintei Treimi"73. Lucrarea Sfintei Treimi s-a adeverit în mod concret pe muntele Taborului: „că Cel ce a grăit de demult prin Lege şi prin prooroci este Dumnezeu, Căruia şi glasul Tatălui din nor luminos I-a mărturisit, zicând: Pe Acesta să-L ascultaţi, Care prin Cruce va prăda iadul şi va dărui morţilor viaţă veşnică"74.

\section{d) Lumina slavei celei dumnezeieşti}

Cântările praznicului scot în evidenţă faptul că omul nu se poate învrednici să vadă slava lui Dumnezeu dacă simţurile sale psiho-fizice nu sunt întărite şi luminate de energiile îndumnezeitoare ale Creatorului, iar la această treaptă nu ajung decât cei ce s-au curăţit de patimi şi au atins culmile trăirii duhovniceşti. Hristos se descoperă pe Sine şi îi iluminează pe oameni în funcţie de curăţia inimii lor. Pe Tabor, Mântuitorul le-a arătat ucenicilor că de vor străluci cu mulţimea virtuţilor, se vor învrednici şi de dumnezeiasca slavă.

De asemenea, trebuie amintită manifestarea transfigurării lui Hristos în contemplarea lui Hristos „desfigurat” de patimile Sale.

72 Ibidem, Stihoavna Vecerniei Mari, p. 76.

73 Vladimir Lossky, Teologia mistică a Bisericii de Răsărit, trad. Vasile Răducă, Bucureşti, Edit. Anastasia, 1990, p. 178.

74 ***, Mineiul pe August, Stihira a treia de la Doamne strigat-am..., Vecernia Mare, p. 72. 
Şi, astfel tot creştinul poate deveni un participant al Schimbării. Unii Sfinţi Părinţi văd în unele dintre cântările praznicului dumnezeirea Sfintei Treimi, sau numai a Dumnezeirii lui Hristos. „Cela ce este Lumină mai înainte de soare, Hristoase, astăzi în muntele Taborului, cu taină chipul Treimmii 1-a arătat" (marea stihiră de la Litie, Mineiul pe August, ziua a şasea) ${ }^{75}$. Şi tot în această cântare se spune că Hristos, Schimbându-Se la Faţă, ca Unul Care stăpâneşte peste cei vii şi peste cei morţi ,a adus pe cei mari dintre prooroci, pe Moise şi pe Ilie, ca să mărturisească Dumnezeirea Lui" ${ }^{\prime 76}$. Aceeaşi idee se află şi în alte imne:

Şi, vorbind împreună cu Moise şi cu Ilie a arătat că El stăpâneşte peste cei vii şi peste cei morţi. Şi cum Cel ce a grăit de demult prin Lege şi prin prooroci este Dumnezeu, Căruia şi glasul Tatălui i-a mărturisit din nor luminos, zicând: „Pe Acesta ascultaţi-L”. Care va prăda iadul prin Cruce, şi va dărui morţilor viaţă veşnică" (Stihira a 3-a, Vecernia Mare);

„Cela ce ţii viaţa şi stăpâneşti moartea, ai pus de faţă pe Moise şi pe Ilie care au mărturisit a Ta Dumnezeire" (Cântarea a 5-a $)^{77}$.

\section{e) Schimbarea la Faţă a Domnului - Teofania prin excelenţă}

Pe muntele Tabor, Tatăl confirmă mărturisirea lui Petru potrivit căreia profeţiile vetero-testamentare se împlinesc în Persoana Fiului Omului: „Tatăl va mărturisi Fiu pe Cel ce se schimbă la faţă..." (Canonul Înainteprăznuirii, Cântarea I) ${ }^{78}$. Se poate observa că în icoana Transfigurării, glasul Tatălui ceresc este reprezentat prin Mâna dumnezeiască.

Deseori, s-a făcut o paralelă între taina Schimbării la faţă cu o altă manifestare nu mai puţin la fel de tainică, şi anume, a botezului lui Hristos în Iordan. Privind ambele manifestări, se face

75 Ibidem, p. 74.

${ }^{76}$ Ibidem.

77 Ibidem, p. 74, 82.

${ }^{78}$ Ibidem, p. 81. 
în schimb auzită vocea Tatălui: „Acesta este Fiul meu mult iubit şi în care am binevoit".

Schimbarea la Faţă descoperă icoana Sfintei Treimi, precum şi unitatea în fiinţă a celor trei Persoane treimice. Astfel, imnele slujbei zilei de 6 august dau mărturie:

„Cel ce este lumină mai înainte de soare, Hristos, trupeşte pe pământ vieţuind şi mai înainte de Cruce toate cele ce erau din înfricoşătoarea rânduială săvârşindu-le cu dumnezeiască cuviinţă, astăzi în Muntele Taborului, cu taină chipul Treimii l-a arătat" (stihiră la Litie);

„Schimbându-Te la Faţă în Muntele Taborului, Mântuitorule al meu Preabunule, lămurit s-a cunoscut slava Treimii" ( 9 august, stihirile de la Laude) ${ }^{79}$.

Stihirile de la Stihoavnă din 10 august vorbesc despre „slava Darului cel în trei sori”, despre lumina descoperită pe muntele Tabor, în care ,am văzut Lumină pe Tatăl şi pe Duhul, Care aduce la lumină toată făptura" (Luminânda praznicului).

\section{f) Natura luminii lui Hristos de pe Tabor}

Textele liturgice ne înfăţişează faptul că la Schimbarea la Faţă pe Tabor, faţa lui Hristos strălucea asemeni soarelui: „Fulgerul feţei Tale cel mai tare decât vederea omenească" ${ }^{\circ 0}$. Strălucirea feței lui Hristos în Tabor este legată de natura Sa Dumnezeiască. Astfel, imnul liturgic aminteşte realiteatea că: „,Cel ce mai înainte de veci eşti Dumnezeu Cuvântul, Care Te îmbraci cu lumina ca şi cu o haină, schimbându-Te la faţă înaintea ucenicilor Tăi, ai strălucit mai mult decât soarele..."81. Sfântul Maxim Mărturisitorul, tâlcuind semnificaţia veşmintelor luminoase cu care era îmbrăcat Hristos în momentul Schimbării la Faţă, afirmă că:

${ }^{79}$ Ibidem, p. 73, 84.

${ }^{80}$ Ibidem, Utrenia, Canonul al II-lea, Cântarea a 8-a, troparul al 2-lea, p. 74.

${ }^{81}$ Ibidem, Utrenia, la Laude, Stihira a 2-a, p. 86. 
„modul afirmativ de cunoaştere a lui Dumnezeu se împarte în cel bazat pe lucrare, pe pronie şi pe judecată. Cel bazat pe lucrare, care prin frumuseţea şi măreţia făpturilor dă ştirea că Dumnezeu este Creatorul tuturor, e simbolizat de veşmintele strălucitoare ale Domnului, pe care Cuvântul le-a arătat cu anticipaţie în făpturile văzute" ${ }^{82}$.

Văzându-L pe Domnul în lumina strălucitoare, Apostolii Petru, Ioan şi Iacob au fost şi ei iluminaţi. Imnografia acordă un loc aparte temei strălucirii Luminii dumnezeieşti, însă accentul se pune pe participarea la Lumină, pe iluminarea omului. Slava lui Dumnezeu îl luminează pe om. În icoană, această participare este reprezentată prin razele de lumină care îi ating atât pe cei trei ucenici, cât şi pe profeţii Moise şi Ilie.

Imnografia Schimbării la Faţă proclamă dogma ortodoxă a luminii necreate care s-a manifestat pe Muntele Tabor. Icoana proclamă şi ea, prin mijloacele de exprimare specifice, această dogmă. Dacă aurul oricărei icoane este deja simbolul luminii cereşti, icoana Schimbării la Faţă ne înfăţişează într-un mod şi mai explicit lumina dumnezeiască, inefabila splendoare a unei singure firi în trei ipostasuri.

Lumina lui Hristos este, de altfel, revărsarea peste El a luminii Sfintei Treimi, după cum ne încredinţează Luminânda Praznicului: „Cuvinte Cel ce eşti lumină neschimbată a Tatălui luminii Celui nenăscut, în lumina Ta, arătată astăzi în Tabor, am văzut Lumină pe Tatăl, Lumină pe Duhul, care aduce la lumină toată făptura" ${ }^{93}$.

În privinţa naturii luminii de pe Tabor în care a fost învăluit Hristos, textul liturgic mărturiseşte: „Foc fără materie a fost văzut nearyând materia trupului, precum Te-ai arătat..." ${ }^{\text {"84 }}$. Lumina treimică ce a strălucit pe chipul omenesc al lui Hristos îmbracă trupul material al Domnului, fiindcă lumina dumnezeiască a lui Hristos nu a ars

82 Sfântul MAXIM MĂRTURISITORUL, Ambigua (Părinţi şi Scriitori bisericeşti, 80), trad. Dumitru Stăniloae, Bucureşti, Edit. Institutului Biblic şi de Misiune al Bisericii Ortodoxe Române, 1987, p. 125-126.

83 ***, Mineiul pe August, Utrenia, Luminânda, p. 78.

84 ***, Mineiul pe August, Utrenia, Canonul al II-lea, Cântarea a 4-a, troparul al 4lea, p. 80. 
materia trupului Său. Putem spune astfel că, în Tabor, ,,pentru prima dată se descoperă însăşi dumnezeirea ascunsă în trup a Logosului" 85 .

În acest sens putem cugeta că ,lumina taborică este manifestarea inteligibilă a slavei dumnezeieşti. Din punct de vedere gnoseologic, această lumină este, ca şi celelalt energii divine, dumnezeiască şi îndumnezeitoare, distinctă, dar inseparabilă de fiinţa lui Dumnezeu"86. Sfântul Simeon Noul Teolog, zice despre această Lumină dumnezeiască arătată în Tabor:

\begin{abstract}
„Aşadar, acest foc dumnezeiesc ce fel de foc socoteşti că este? Oare unul văzut, creat sau sensibil? Nicidecum, căci eşti iniţiat în taina unui astfel de foc şi ştii bine că acesta este necreat, nevăzut, neînceput şi nematerial, cu totul neschimbabil şi de asemenea necircumscris, de neatins, nemuritor, necuprins cu totul, în afara tuturor făpturilor celor materiale şi imateriale, văzute şi nevăzute, trupeşti şi netrupeşti, pământeşti şi cereşti, fiind în afara tuturor acestora prin fire, prin fiinţă şi prin putere..." ${ }^{97}$.
\end{abstract}

Sfântul Maxim Mărturisitorul numeşte lumina în care a apărut Hristos pe Tabor ,simbol prin care a descoperit dumnezeirea mai presus de minte... iar veşmântul Său alb ca zăpada, simbol al celui ce poartă puterea Raţiunii creatoare" 88 . Lumina strălucitoare în chip orbitor de pe Tabor ,,albul strălucitor al veşmintelor Domnului, norul luminos care-1 învăluie pe Iisus, iar pe Apostoli îi face să se arunce la pământ de teamă, sunt tot atâtea manifestări ale prezenței Duhului, semne ale bunăvoirii Tatălui în Fiul Său Cel Preaiubit"89.

85 Benedict GHIUŞ, Taina Răscumpărării în imnografia Ortodoxă, Bucureşti, Edit. Institutului Biblic şi de Misiune al Bisericii Ortodoxe Române, 1998, p. 113.

86 Nicolae MoşoıU, Taina prezenţei lui Dumnezeu în viaţa umană. Viziunea creatoare a părintelui profesor Dumitru Stăniloae, Braşov, Edit. Paralele, 2000, p. 198.

${ }^{87}$ Sfântul Simeon Noul TeOlog, Imne. Epistole şi Capitole, Scrieri - partea a IIIa, trad. Ioan I. Ică jr., Sibiu, Edit. Deisis, 2001, p. 183.

${ }^{88}$ Sfântul MAXIM MĂRTURISITORUL, op. cit., p. 125-126.

89 Boris Bobrinskoy, Împărtăşirea Sfântului Duh, trad. Măriuca şi Adrian Alexandrescu, Bucureşti, Edit. Institutului Biblic şi de Misiune al Bisericii Ortodoxe Române, 1999, p. 26. 
Vederea luminii necreate pe Tabor este tot una cu vederea Împărăţiei lui Dumnezeu. Sfântul Grigorie Palama zice în acest sens că „aici El (Hristos, subl.n.) numeşte Lumina propriei Sale Schimbări la Faţă, Slava Tatălui şi a Împăţiei Sale" ${ }^{\prime 0}$. Aşadar, „Împărăţia lui Dumnezeu este de fapt lumina necreată, care reprezintă hrana fiinţelor cereşti, substanţa bunătăţilor ce au să fie, Împărăţia enipostatică. Participarea la această Lumină înseamnă participarea la Împărăţia lui Dumnezeu" "91.

\section{Concluzii}

Sărbătorile reprezintă atât în viaţa Bisericii, cât şi a credincioşilor în particular, popasuri duhovniceşti în care ne întâlnim cu Dumnezeu şi petrecem cu Sfinţii Săi. Acestea au apărut datorită necesităţilor spirituale ale omului, de a preamări pe Dumnezeu, arătându-I recunoştinţă, şi de a lăuda pe Sfinţi. Starea de serbare este una de contemplare, prin care omul apare în istorie şi tot cu ea intră în veşnicie ${ }^{92}$.

Schimbarea la Faţă a Domnului se află în centrul Teologiei ortodoxe, pentru că reprezintă confirmarea posibilităţii omului de aL cunoaşte pe Dumnezeu. Astfel, în cadrul sărbătorii Transfigurării Domnului, credinciosul face un exerciţiu duhovnicesc pentru a fi cuprins de starea de contemplare, stare caracteristică cultului ortodox. În acest sens, teologul Vladimir Lossky dă mărturie, spunând: „Tema Schimbării la Faţă a lui Hristos revine constant la teologii bizantini: ea va fi cheia de boltă a învăţăturii lor despre vederea lui Dumnezeu"93.

${ }^{90}$ Sfântul Grigorie Palama, Două cuvântări la Cinstirea Schimbarea la faţă a Mântuitorului Iisus Hristos. Omilia a 34-a, 3, trad. Eugen Moraru, în Revista Teologică 3 (1991), p. 35.

${ }^{91}$ Mitropolitul Hierotheos Vlachos, Predici la marile sărbători, trad. Daniela Filioreanu, Galaţi, Edit. Egumeniţa, 2004, p. 336.

92 Viorel SAVA, „Sărbătorile împărăteşti ale Mântuitorului - Evaluare în perspectiva dialogului ortodox-romano-catolic", în Dialog teologic 4 (1999), p. 174.

${ }^{93}$ Vladimir Lossky, Vederea lui Dumnezeu, trad. M.C. Oros, Sibiu, Edit. Deisis, 1995, p. 32. 
Sărbătoarea Schimbării la Faţă a Domnului este ultimul praznic cu dată fixă din cursul anului bisericesc. După cum am putut observa în studiul de faţă, această sărbătoare poate fi datată ca şi generalizare în veacul al XV-lea. Tradiţia bisericească pune în lumină mărturii inedite care confirmă celebrarea evenimentului de pe Tabor încă din secolul al V-lea. Ridicarea celor trei biserici (basilici) pe Tabor, una datând din timpul împărătesei Elena, confirmă importanţa deosebită, pe care Biserica a acordat-o încă de la început sărbătorii Transfigurării Domnului. Astfel, aflăm din mărturiile istoricilor faptul că Muntele Tabor - locul unde Iisus Hristos S-a schimbat la Faţă înaintea celor trei ucenici Petru, Iacov şi Ioan, a fost considerat încă din veacul al IV-lea, un spaţiu sfânt.

Imnografia praznicului oferă sărbătorii o frumuseţe aparte. Imnele alcătuite în mare parte de Ioan Damaschin şi de fratele său adoptiv, Cosma, sunt expresia hristologiei formulată în primele veacuri, la sinoadele ecumenice. Invăţătura de credinţă despre Fiul lui Dumnezeu Întrupat se descoperă în textele poetice ale praznicului. Astfel, troparul Schimbării la Faţă cuprinde sinteza înţelesurilor duhovniceşti ale praznicului: ,Schimbatu-Te-ai la faţă, în munte, Hristoase Dumnezeule, arătând ucenicilor Tăi slava Ta, pe cât li se putea; strălucească şi nouă, păcătoşilor, lumina Ta cea pururea fiitoare, pentru rugăciunile Născătoarei de Dumnezeu, Dătătorule de lumină, slavă Ţie!" 94 .

Schimbarea la Faţă reprezintă o adevărată teofanie trinitară: Tatăl dă mărturie despre Fiul, iar Fiul străluceşte în lumina cea veşnică, împărtăşită cu Duhul, aşa cum la botezul în apa Iordanului, Tatăl din cer glăsuieşte şi Duhul se arată în energiile Sale prin Hristos, care se identifică cu Logosul şi se face lumină. Dacă Epifania presupune o lucrare sfinţitoare, iar Cincizecimea introduce în teognosie, Schimbarea la Faţă arată lumina, căci Lumină este Tatăl, Lumină este Fiul, Lumină este Duhul Sfânt.

Transfigurarea Domnului pe Muntele Tabor este şi garanţia transfigurării noastre şi chiar a îndumnezeirii. Mântuitorul Iisus Hristos ne încredinţează că, în împărăţia lui Dumnezeu, drepţii vor

94 ***, Mineiul pe August, p. 71. 
străluci ca soarele. Apariţia Fiului lui Dumnezeu în lumină pe Tabor, ne încredinţează că vom vedea pe Dumnezeu ca lumină prin lumina Lui, aşa cum L-au văzut Apostolii. Aceasta este împlinirea cuvintelor psalmistului: „Intru lumina Ta vom vedea lumină” (Ps. 35, 9).

Experienţa pe care avut-o pe Tabor se prelungeşte şi se actualizează în cultul divin, în special în Sfânta Liturghie, împărtăşindu-se de ea fiecare credincios ${ }^{95}$. Astfel, în finalul Sfintei Liturghii, în Ortodoxie, după ce credincioşii se împărtăşesc cu Trupul şi Sângele Domnului, se cântă: „Am văzut Lumina cea adevărată, am primit Duhul cel ceresc, am aflat credinţa cea adevărată, nedespărţitei Sfintei Treimi închinându-ne, că Aceasta ne-a mântuit pe noi" 96 .

$\cos 80$

\section{Bibliografie}

\section{A. Izvoare:}

1.***, Mineiul pe August, Bucureşti, Edit. Institutului Biblic şi de Misiune al Bisericii Ortodoxe Române, 2003.

2. EusEBIU DE CEZAREEA, Istoria Bisericească, trad. Teodor Bodogae (Părinţi şi Scriitori bisericeşti, 12), București, Edit. Institutului Biblic şi de Misiune al Bisericii Ortodoxe Române, 1987.

3. Sfântul GRIGORIE PALAMA, Despre lumina sfântă, în vol. Filocalia sau Culegere din Scrierile Sfinţilor Părinţi care arată cum poate omul curăti, lumina şi desăvârşi, trad. Dumitru Stăniloae, Bucureşti, Edit. Institutului Biblic şi de Misiune al Bisericii Ortodoxe Române, 1977.

4. IDEM, Două cuvântări la Cinstirea Schimbarea la faţă a Mântuitorului Iisus Hristos. Omilia a 34-a, trad. Eugen Moraru, în Revista Teologică 3 (1991), p. 34-44.

5. METODIU DE OLIMP, Banchetul sau despre castitate, trad. Constantin Corniţescu (Părinţi şi Scriitori bisericeşti, 10),

95 Viorel SAVA, art. cit., p. 175.

${ }^{96}$ Petre Vintilescu, Liturghierul explicat, Bucureşti, Edit. Institutului Biblic şi de Misiune al Bisericii Ortodoxe Române, 1998, p. 333. 
Bucureşti, Edit. Institutului Biblic şi de Misiune al Bisericii Ortodoxe Române, 1984.

6. Sfântul IOAN DAMASCHIN, „Cuvânt la Schimbarea la Faţă a Domnului şi Mântuitorului nostru Iisus Hristos", în vol. Cuvântări la sărbători împărăteşti, la sărbători ale Maicii Domnului şi la Sfinţi, trad. Gabriel Mândrilă şi Laura Mândrilă, Bucureşti, Edit. Institutului Bibilic şi de Misiune Ortodoxă, 2010.

7. Sfântul MAXIM MĂRTURISITORUL, Ambigua (Părinţi şi Scriitori bisericeşti, 80), trad. Dumitru Stăniloae, Bucureşti, Edit. Institutului Biblic şi de Misiune al Bisericii Ortodoxe Române, 1987.

8. Sfântul Simeon Noul Teolog, Imne. Epistole şi Capitole, Scrieri - partea a III-a, studiu introductiv, trad. Ioan I. Ică jr., Sibiu, Edit. Deisis, 2001.

9. Timothei ANTIOCHENI, In Crucem et in Transfigurationem, PG $86,255 \mathrm{~A}-266 \mathrm{~B}$.

10. Tissot (ed.), Gabriel, Ambroise de Milan, Traité sur l'Évangile de S. Luc, tome I (Sources Chrétiennes 45), Paris, Éditions du Cerf, 1976.

11. Tonneau (ed.), R. M., S. Cyrilli Alexandrini Commentarii in Lucam: Pars Prior (Corpus Scriptorum Christianorum Orientalium, 140: Scriptoris Syri 70), Louvain, Dubecq, 1953.

\section{B. Literatură secundară:}

12. ANDREOPOULOS, Andreas, Metamorphosis. The Transfiguration in Byzantine Theology and Iconography, St. Vladimir's Seminary Press, New York, Crestwood, 2005.

13. BoBRINSKOY, Boris, Impărtăşirea Sfântului Duh, trad. Măriuca şi Adrian Alexandrescu, Bucureşti, Edit. Institutului Biblic şi de Misiune al Bisericii Ortodoxe Române, 1999.

14. BRANIŞTE, Ene, Liturgica generală, Edit. Institutului Biblic şi de Misiune al Bisericii Ortodoxe Române, Bucureşti, 1993.

15. IDEM/, BRANIŞTE, Ecaterina, Dicţionar de cunoştinţe religioase, Sibiu, Edit. Andreiană, 2010. 
16. Coune, Dom Michel, obs. Moine de Sainte-André-lez-Bruges, Joie de la Transfiguration, D'Après les Pères D'Orient (Spiritualite Orientale, 39), Paris, Abbaye de Bellefontaine, 1985.

17. GHIUŞ, Benedict, Taina Răscumpărării în imnografia Ortodoxă, Bucureşti, Edit. Institutului Biblic şi de Misiune al Bisericii Ortodoxe Române, 1998.

18. FARCAȘIU, Lucian, „Teologia imnografică a Praznicului Schimbării la Faţă a lui Hristos", în Teologia 3 (2005), p. 104-117.

19. LEBEDEW, Petru, Liturgica sau explicarea serviciului divin, trad. în rom. şi prelucrare de Iconom Nicolae Filip, Bucureşti, 1899.

20. Lossky, Vladimir, Teologia mistică a Bisericii de Răsărit, trad. Vasile Răducă, Bucureşti, Edit. Anastasia, 1990.

21. IDEM, Vederea lui Dumnezeu, trad. M.C. Oros, Sibiu, Edit. Deisis, 1995.

22. MANEA, Vasile, Intâlnirea cu Dumnezeu exprimată în icoana Schimbării la Faţă, Cluj-Napoca, Edit. Patmos, 2006.

23. Miron, Vasile, Sărbătorile impărăteşti cu dată fixă în cinstea Mântuitorului. Istoricitatea, semnificaţia şi importanţa lor liturgică, religioasă şi etnografică, Bucureşti, Edit. Paideia, 2010.

24. MitrofanovicI, Dr. Vasile, Prelegeri academice despre Liturgica Bisericii dreptcredincioase răsăritene, Cernăuţi, 1909.

25. MocA, Dumitru, „Sărbătoarea Schimbării la Faţă a Domnului, consideraţii istorico-liturgice", în Altarul Banatului 7-9 (2001), p. 35-41.

26. MoşorU, Nicolae, Taina prezenţei lui Dumnezeu în viaţa umană. Viziunea creatoare a părintelui profesor Dumitru Stăniloae, Braşov, Edit. Paralele, 2000.

27. Pletosu, Gh., „Cuvânt la 6 august. Schimbarea la Faţă a Domnului”, în Revista Teologică 3 (1909), p. 337-341.

28. PRELIPCEAN, Alexandru, „Gematria ebraică - paradigmă ermineutică a Sfintei Scripturi. Studiu de caz: cifrele 1-7 în cartea Facere”, în Studii Teologice 2 (2008), p. 177-212.

29. RAMSEY, Arthur Michael, The Glory of God and the Transfiguration of Christ, Oregon, Wipf Stock Eugene, 2009.

30. Rouillard, Philippe, Les fetes chretiennes en Occident, Paris, Les Éditions du Cerf, 2003. 
31.SAVA, Viorel, „Sărbătorile împărăteşti ale Mântuitorului Evaluare în perspectiva dialogului ortodox-romano-catolic", în Dialog teologic 4 (1999), p. 174-187.

32. STĂNILOAE, Dumitru, „Drumul cu Hristos Mîntuitorul prin Tainele şi sărbătorile Bisericii Ortodoxe”, în Ortodoxia 2 (1976), p. 402-421.

33. IDEM, Viaţa şi învăţătura Sfântului Grigorie Palama, Bucureşti, Edit. Scripta, 1993.

34. SteVenson, Kenneth, Rooted in Detachment.Living the Transfiguration, Michigan, Cistercian Publications, 2007.

35. USPENSKY, Leonid/, USPENSKY, Vladimir, Călăuziri în lumea icoanei, trad. Anca Popescu, Bucureşti, Edit. Sofia, 2003.

36. VINTILESCU, Petre, Liturghierul explicat, Bucureşti, Edit. Institutului Biblic şi de Misiune al Bisericii Ortodoxe Române, 1998.

37. IDEM, Despre poezia imnografică din cărţile de ritual şi cântarea bisericească, Cluj-Napoca, Edit. Partener, ${ }^{2} 2006$.

38. Vlachos, Mitropolitul Hierotheos, Predici la marile sărbători, trad. Daniela Filioreanu, Galaţi, Edit. Egumeniţa, 2004.

39. Von EsbroeK, M., „Une homelie georgienne anonyme sur la Transfiguration", în Orientalia Christiana Periodica 46 (1980), p. 418-445. 